$$
\begin{gathered}
\text { 상향링크 셀룰러 시스템에서 그룹 탐색 기반의 분산동적채널할당 방법 } \\
\text { 유 도 경a), 김 동 회 }{ }^{\natural}
\end{gathered}
$$

\title{
A Group Search-based Distributed Dynamic Channel Allocation Algorithm in Uplink Cellular System
}

\author{
Doh-kyoung Yoo ${ }^{\text {a)}}$, and Dong-hoi Kim ${ }^{\text {a) }}$
}

요 약

주파수 재사용률 1을 사용하는 상향링크 셀룰러 시스템의 동적채널할당 (DCA : Dynamic Channel Allocation) 방법에서는 신규호 가 채널 할당을 요구할 때 신규호의 SINR (Signal to Interference and Noise Ratio)이 요구된 SINR 보다 작거나 할당할 채널이 부족 한 경우에 신규호 차단이 발생한다. 이러한 차단된 신규호에 대한 추가적인 채널할당을 위하여 인접한 셀에서 채널을 가져오게 된다. 이 경우에 동일 채널 간섭 (CCI: Co-Channel Interference)이 발생하게 되고 이로 인해 기존 호의 SINR이 저하되어 기존 호에 대한 채널 재할당을 해야 하는 경우가 생기게 된다. 따라서 신규호 블록율이 증가할수록 인접한 셀에서 채널을 가져오는 경우의 수를 증가 시킴으로써 채널 재할당 과정은 복잡한 연산과정이 필요한 NP-hard 문제가 된다. 그 문제를 해결하기 위하여 본 논문에서는 차단된 신규호를 감소시킴으로써 추가적인 채널할당을 위하여 인접한 셀에서 채널을 가져오는 횟수를 감소시키고 그 결과로 채널 재할당 횟 수가 감소되어 복잡한 연산과정을 피할 수 있는 Group Search-based DCA 방법을 제안한다. 제안한 방법은 신규호의 차단율을 감소 시키기 위하여 신규호에 대한 채널할당시 단말이 속해 있는 셀뿐만 아니라 그 주변의 셀까지를 한 그룹으로 묶어서 채널 탐색 범위를 확장하는 방법을 사용한다. 시뮬레이션 결과에서 제안한 Group Search-based DCA가 탐색 범위를 단말이 속한 셀로 한정하는 Single Search-based DCA보다 신규호 차단률과 시스템 수율 성능을 향상시킴을 확인할 수 있었다.

\begin{abstract}
In DCA (Dynamic Channel Allocation) scheme of uplink cellular system appling a frequency reuse factor of one, when a new call requests a channel, the new call will be blocked if its SINR (Carrier to Noise and Interference Ratio) is less than the required SINR or there is no available channel. The additional channel allocation for the blocked new call can be performed with channel borrowing in the adjacent cells. The channel borrowing causes the CCI (Co-Channel Interference), thus the SINR of the existing calls is deteriorated and the channel reallocation for the existing calls is required. As a result, the channel borrowing leads to a complex calculation so that it is a NP-hard problem. Therefore, to overcome the problem, we propose a novel Group Search-based DCA scheme which decreases the number of the blocked new calls and then reduces the number of the channel reallocation by the channel borrowing for the blocked new calls. The proposed scheme searches the all channels in a group of the adjacent cells and home cell at the same time in order to minimizes the number of the blocked new calls. The simulation results show that proposed Group Search-based DCA scheme provides better new call blocking probability and system throughput than the existing Single Search-based DCA scheme which searches only the channels in home cell.
\end{abstract}

Keyword : Dynamic Channel Allocation, Co-Channel Interference, Signal to Interference and Noise Ratio, Channel Borrowing, Block Probability, System Throughput 


\section{I. 서 론}

무선 셀룰러 통신 시스템에서 한정된 자원인 주파수를 효 율적으로 이용하기 위해서 서비스 지역을 셀이라는 작은 구 역으로 나누어 채널을 할당하는 셀룰러 통신모델을 사용하 게 된다. 셀룰러 통신에서는 주파수 재사용이라는 개념을 이용하게 되는데, 이는 동일한 주파수를 사용하는 셀들을 어느 정도의 간섭만 영향을 미치도록 떨어뜨려 서비스 지역 내의 사용가능한 채널의 양을 늘리는 방법이다 ${ }^{[1][2]}$. 셀룰러 통신 모델에서 채널을 할당하는 방법에는 크게 고정채널할 당 (FCA : Fixed Channel Allocation)와 동적채널할당 방법 이 있다 ${ }^{[3]}$. 주파수 자원의 효율적인 이용으로 시스템 수용능 력을 증대시키기 위해서 동적채널할당 방법을 사용한다. 동 적채널할당 방법에는 중앙집중형과 분산형이 있다. 중앙집 중형은 단말과 기지국 사이에서 사용되고 있는 채널의 상황 을 관리국이 종합적으로 제어, 관리하는 반면 분산형은 각 셀에서 독립적으로 채널을 할당하게 된다.

분산형 동적채널할당 방법에서는 신규호의 요구량이 특 정셀에 집중되면 인접한 셀에서 채널을 가져와 할당할 수 있기 때문에 주파수 재 사용률이 1 인 셀룰러 환경에서는 인접한 셀의 채널을 가져와 사용할 경우 심한 동일 채널 간섭을 일으키게 되므로 채널을 가져올 경우에 인접한 셀 들의 간섭파를 측정하여 단말의 반송파와 간섭파의 전력비 인 SINR을 산출한 후 주어진 SINR 문턱치값을 만족하면 채널을 할당하고 그렇지 않으면 채널을 해당할지 못하게 되는 SINR 기반이 동적채널할당 방식이 많이 사용된다 ${ }^{[4]}$. 그러한 방법들은 채널을 할당함에 있어서 우선적으로 채널 탐색 범위를 단말이 위치한 셀로 한정하고 그 후에 SINR 문턱치값을 만족하지 못하는 경우에만 인접셀에서 채널을 가져오는 방법들이 많이 연구되었다 ${ }^{[5][6]}$. 그러나 인접셀로 부터 채널을 가져오는 경우에 주변셀에서의 동일 채널 선 택으로 인해 기존셀에서도 동일 채널 간섭을 제공하기 때 문에 신규호의 블록율이 증가하는 경우에는 위와 같은 상

a) 강원도 춘천시 강원대학교 IT대학 전기전자공학부 전자통신공학과 Kangwon National University, College of Information Technology, Dept. of Electrical and Electronic Engineering

‡ 교신저자 : 김동회(dongh@kangwon.ac.kr)

· 접수일(2010년1월29일), 수정일(2010년4월20일),게재확정일(2010년4월23일)
황들을 고려하면서 최적의 채널을 선택하는 문제가 많은 연산과정을 요구되는 일종의 NP-hard 문제가 된다 ${ }^{[7][8]}$. 또 한 기존에는 동적채널할당에 대한 연구들이 하향링크에 대 해서는 많이 진행되었지만 상향링크 동적채널할당에 대해 서 많은 연구가 진행되어 않았다. 따라서 본 논문에서는 상 향링크 셀룰러 시스템에서 SINR 기반으로 동적 할당을 할 때 채널 탐색 범위를 단말이 속한 주변의 셀까지 확장하여 채널을 할당하는 Group Search-based DCA을 제안한다. 제 안한 방식은 채널 탐색 범위를 단말이 위치한 셀로 한정하 여 채널을 할당하는 기존의 Single Search-based DCA에 비 하여 단말이 위치한 셀에서 할당 가능한 채널이 없는 경우 나 셀 경계에 위치해 있어 열악한 SINR를 가진 신규호들의 블록율을 감소시켜줌으로써 인접셀로부터 채널을 가져올 때 발생하는 연산과정의 복잡성 문제를 해결하는데 도움이 될 수 있다.

본 논문에서는 제안하는 상향링크 Group Search-based Max DCA 알고리즘의 신규호 블록율과 시스템 수율값을 기 존의 상향링크 Single Search-based Random DCA 알고리즘 과 비교분석하였다. 본 논문의 구성은 다음과 같다. 피장에서 는 본 논문에서 고려하는 상향링크 셀룰러 시스템 모델을 살 펴보고, III장에서는 기존의 Single Search-based Random DCA 알고리즘과 제안하는 Group Search-based Max DCA 알고리즘을 비교할 것이다. IV장에서는 시뮬레이션 결과에 대해 기술하고, 마지막으로 $\mathrm{V}$ 장에서는 결론을 맺는다.

\section{II. 상향링크 시스템 모델}

셀룰러 시스템에서는 이동통신 서비스 지역을 셀이라는 작은 구역으로 분리하여 제한된 주파수 자원을 효율적으로 사용하게 된다. 셀 영역 안에 있는 단말이 호를 요구하면 각 셀의 중심에 있는 기지국에서 이들에게 적당한 채널을 할당 하게 된다. 단말이 통화중에 인접 셀로 이동하게 되면 핸드 오버가 이루어져 호의 단절 없이 통화를 이어갈 수 있다.

그림 1 에서 기지국 $\mathrm{B} 0, \mathrm{~B} 1, \mathrm{~B} 2$ 는 각각 단말 $\mathrm{U} 0, \mathrm{U} 1$, $\mathrm{U} 2$ 에 연결되어 있으며 모두 동일한 주파수의 채널을 사용 하고 있다고 가정하고, 단말 $\mathrm{U} 0$ 에 대한 신호 대 간섭 잡음 
비를 구하면 다음과 같다 ${ }^{[9]}$.

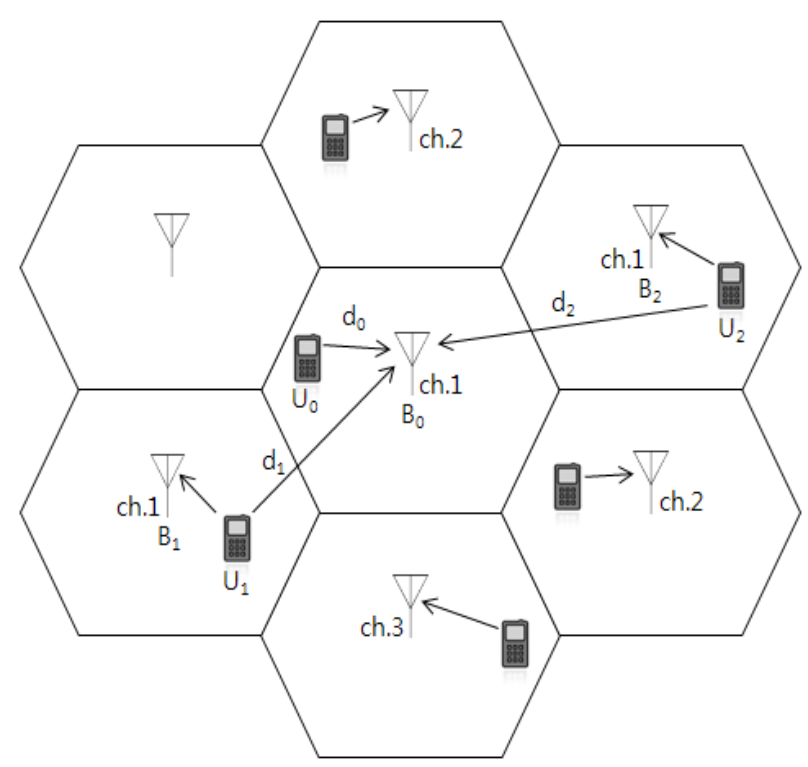

그림 1. 상향링크 셀룰러 시스템 모델

Fig. 1. Uplink cellular system model

$$
C N I R=\frac{A P_{0} d_{0}^{-\alpha} 10^{\frac{\xi_{0}}{10}}}{N+\sum_{i=1}^{2} A P_{i} d_{i}^{-\alpha} 10^{\frac{\xi_{i}}{10}}}
$$

식 (1)에서 $\mathrm{A}$ 는 비례계수, $P_{i}$ 는 단말 $U_{i}$ 의 전송파워, $d_{i}$ 는 단말 $U_{i}$ 와 기지국 $B_{i}$ 의 거리를 나타낸다. $a$ 는 거리 감쇠계수를 나타내고, ㄲi는 새도잉 감쇠를 데시벨로 나타 낸다.

\section{III. 상향링크 동적채널할당 알고리즘}

채널할당방법에는 크게 고정채널할당과 동적채널할당 이 있다. 고정채널할당은 기지국 마다 할당할 수 있는 채널 의 수가 고정되어 있기 때문에 특정 셀에서 할당할 수 있는 채널이 모두 사용 중이면 추가적으로 호가 발생했을 때 인 접한 셀에 사용하지 않는 채널이 있더라도 채널을 할당할 수 없게 되어 신규호의 차단이 일어난다. 이와 같이 특정
셀에 신규호가 몰리게 될 경우 채널의 사용 효율이 낮아질 수밖에 없다. 동적채널할당은 특정 셀에서 할당 가능한 채 널이 없을 경우에 인접한 셀의 채널을 가져와 할당할 수 있는 방법이다. 채널을 사용자의 요구에 따라 유연하게 할 당함으로써 고정 채널 할당에 비해 높은 수용능력을 이룰 수 있다. 또 특정 셀에 호 요구가 몰리더라도 원활하게 채 널을 할당할 수 있게 된다. 동적채널할당 방법에는 중앙집 중형과 분산형이 있다. 중앙집중형은 단말과 기지국 사이 에서 사용되고 있는 채널의 상황을 관리국이 종합적으로 제어, 관리하는 반면 분산형은 각 기지국이 독립적으로 채 널을 할당한다. SINR 기반 분산형은 채널에 대한 단말의 반송파와 간섭파의 전력비인 SINR에 기준하여 사용 가능 한 채널을 독자적으로 할당하는 방식으로 본 논문에서 다 룬 방식이다.

\section{1. 기존의 상향링크 Single Search-based Random 동적채널할당 알고리즘}

SINR 기반 분산형 동적채널할당 알고리즘은 채널 할당 에 있어서 반송파와 간섭파의 전력비인 SINR을 기준으로 한다. 신규호가 발생하면 단말이 속해있는 셀에서 사용가 능한 채널을 찾아 SINR 값을 측정한 후 주어진 SINR 문턱 치값을 만족하면 채널을 할당하게 된다. 만약 SINR 문턱치 값을 만족하지 못하거나 단말이 속한 셀에 사용가능한 채 널이 없는 경우에는 신규호는 차단되기 때문에 인접셀로부 터 채널을 가져오는 방법을 사용한다. 주파수 재사용률이 1 인 셀룰러 환경에서는 인접 셀에서 사용가능한 채널을 가 져올 경우에 또 다시 기존셀에 주는 동일 채널 간섭에 의한 기존호의 SINR값이 변경되기 때문에 기존호에 대한 채널 재할당을 수행해야 한다. 위와 같이 차단된 신규호의 수가 증가할수록 인접셀로부터 채널을 가져오는 횟수가 증가하 게 되고 그 결과로 기존호의 재할당 횟수도 동시에 증가하 게 되기 때문에 많은 연산과정을 요구하는 NP-hard 문제가 된다. 예를 들어 주파수 재사용율이 1 인 셀룰라 시스템에서 한 셀에서 최대 $i$ 개의 채널이 존재하고 $\mathrm{j}$ 개의 멀티 셀이 있 는 구조에서 $\mathrm{k}$ 개의 단말이 이미 연결되어 있다면 사용 가능 한 전체 채널의 수는 i x j - k가 된다. 이러한 채널 환경에서 
$\mathrm{L}$ 개의 차단호가 존재한다면 다시 인접 셀에서 사용가능한 채널을 가져오기 위한 경우의 수는 다음과 같다.

$$
(i \times j-k) ! /(i x j-k-L) \text { ! }
$$

여기서 차단된 신규호의 수가 증가 할수록 식 (2)에서와 같이 $\mathrm{L}$ 의 값은 증가하기 때문에 다시 인접 셀에서 사용가 능한 채널을 가져오는 경우의 수는 증가하게 된다. 그림 2 는 기존의 상향링크 Single Search-based Random 동적채널 할당 알고리즘 흐름도이다. 신규호가 발생하면 앞에서 말 한바와 같이 주어진 SINR 문턱치값을 만족하는 채널을 찾 아서 할당하게 된다. 이 때 신규호 차단이 발생하는 경우에 인접셀로부터 채널을 가져오는 방법을 사용한다.

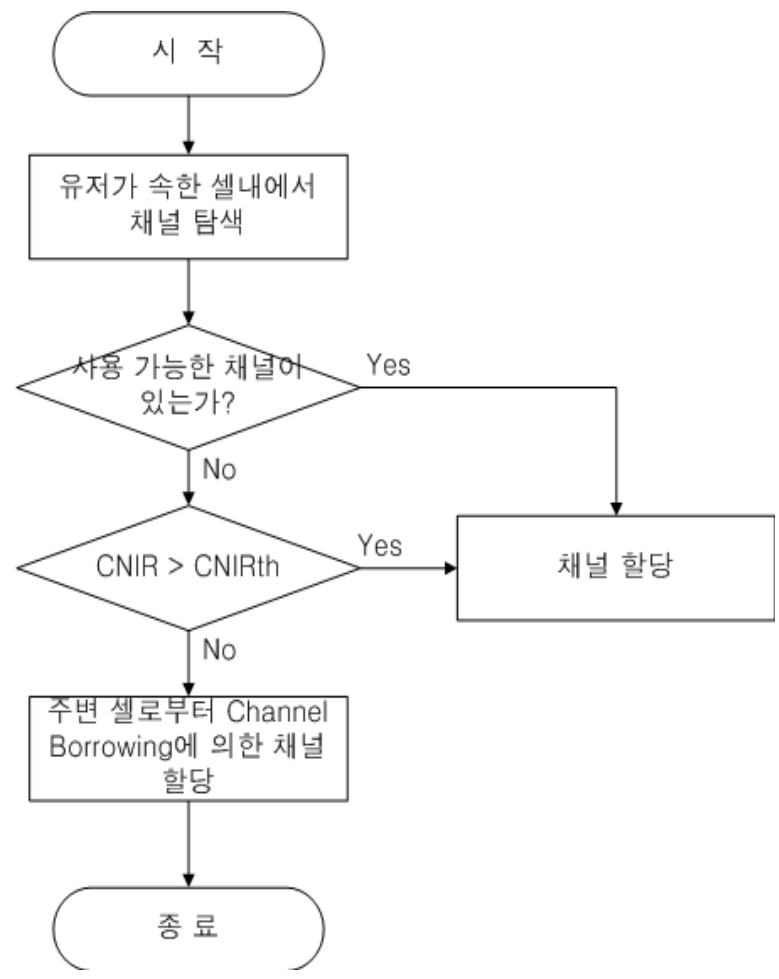

그림 2. 기존의 상향링크 Single Search-based Random 동적채널할당 알고리즘 흐름도

Fig. 2. The flowchart of the existing uplink Single Search-based Random DCA algorithm

\section{2. 제안하는 상향링크 Group Search-based Max 동적채널할당 알고리즘}

기존 상향링크 동적채널할당 알고리즘은 채널을 할당할 때 채널 탐색 범위가 단말이 속해 있는 셀에 한정되기 때문 에 SINR 문턱치값을 만족하지 못하거나 단말이 속한 셀에 사용가능한 채널이 없는 경우에는 신규호는 차단되기 때문 에 차단된 신규호에 대한 채널 할당을 위하여 인접셀로 부 터 채널을 가져올 확률이 증가하게 된다. 이 경우에 주변셀 의 동일 채널 선택으로 인해 기존셀의 동일 채널 간섭이 변하게 되어 기존호에 대한 채널 재할당이 필요하게 되기 때문에 차단된 신규호가 증가한다면 많은 연산과정을 요구 하게 되는 NP-hard 문제가 된다. 따라서 이러한 문제점을 해결하기 위해서 신규호 블록율을 감소시킴으로써 인접셀 로부터 채널을 가져오는 횟수를 줄이는 것이 중요하다. 따 라서 제안하는 상향링크 Group Search-based Max 동적채 널할당 알고리즘은 신규호에 채널을 할당할 때 채널 탐색 범위를 단말이 위치한 셀뿐만 아니라 인접한 셀까지 확장 하여 사용가능한 채널을 찾은 후 SINR 이 주어진 SINR 문 턱치값을 만족하는 채널 중에서 가장 큰 SINR 을 갖는 채 널을 단말에게 할당하게 되기 때문에 호 차단 확률이 급격 히 감소하게 된다. 따라서 식 (2)에서 $\mathrm{L}$ 의 값이 감소하기 때문에 인접 셀에서 사용가능한 채널을 가져오는 경우의 수는 기존 상향 링크 동적채널할당 알고리즘보다 감소된 횟수의 계산식을 수행하면서 주어진 SINR 문턱치값을 만 족하는 채널을 찾아서 할당하게 된다.

그림 3은 제안하는 상향링크 Group Search-based Max 동적채널할당 알고리즘 흐름도이다. 기존 Single Searchbased Random 동적채널할당 알고리즘과 다른 점은 단말이 채널을 할당 받을 셀의 범위가 단말이 속한 셀과 인접한 셀 들로 확대 되었다는 점이다. 따라서 기지국에 가까이 있는 단말의 경우에는 크게 달라지지 않겠지만 거리에 따른 감쇠 나 더 많아지는 장애물들로 인해 반송파의 세기가 감소되어 주어진 SINR 문턱치값을 만족하지 못하게 될 확률이 높은 셀 경계 부근에 위치한 단말의 경우에는 전송품질이 향상되 게 된다. 그러나 제안하는 상향링크 Group Searchbased 


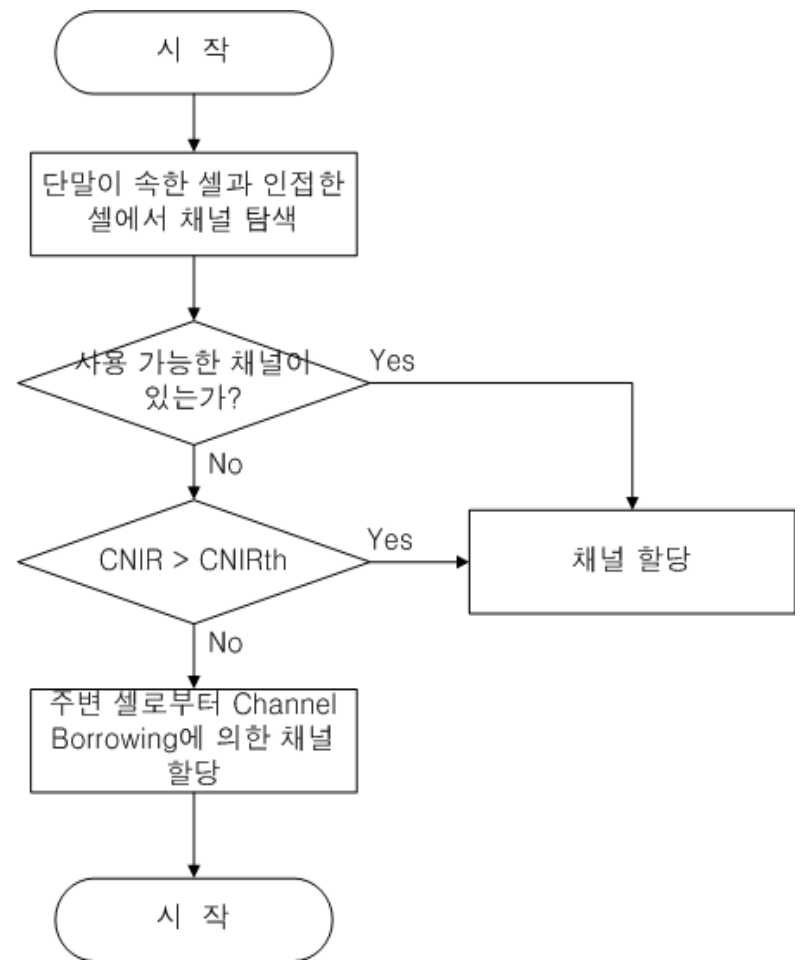

그림 3. 제안하는 상향링크 Group Search-based Max 동적채널할당 알고 리즘 흐름도

Fig. 3. The flowchart of the proposed uplink Group Search-based Max DCA algorithm

Max 동적채널할당 알고리즘을 사용할 경우에 채널 탐색 범위를 인접한 셀까지 확장시켰기 때문에 인접기지국들에 속해 있는 각 단말들의 SINR 정보를 알기 위하여 동일한 그룹으로 묶여있는 셀들간에는 각 단말의 SINR 정보를 교 환을 위한 기지국간의 추가 메시지 교환이 필요하다.

\section{IV. 시뮬레이션 결과}

표 1은 제안하는 상향링크 Group Search-based Max 동 적채널할당 알고리즘의 성능 분석을 위한 파라메타 값들이 다 ${ }^{[10][11]}$. 전체 셀의 수는 셀-랩핑을 고려한 19개 이며, 셀 당 채널의 수는 5 개이다. 또한 셀 당 단말의 수는 5 명에서 25 명까지 2명씩 늘려가며 적용시켰다. 제안하는 GroupSearch-based Max 동적채널할당 알고리즘에서 고려하는
표 1. 시뮬레이션 파라메타

Table 1. The simulation parameter

\begin{tabular}{|c|c|}
\hline Parameter & Value \\
\hline Number of cells & 19 \\
\hline Number of users per cell & $5 \sim 25$ \\
\hline CNR on cell edge & $20 \mathrm{~dB}$ \\
\hline SINR threshold & $15 \mathrm{~dB}$ \\
\hline Average call arrival rate & 6.0 \\
\hline Average call holding time & $120 \mathrm{sec}$ \\
\hline Time length of simulation & $2000 \mathrm{sec}$ \\
\hline
\end{tabular}

Group의 영역은 1-tier로 제한하였다. 총 2000초 진행 동안 10 초마다 호의 상태를 체크하여 최종적으로 신규호 블록율 과 시스템 수율을 구한다.

\section{1. 신규호 블록율}

신규호 블록율은 발생한 신규호 중에서 기지국으로부터 채널을 할당받지 못하고 차단된 호의 비율이다.

$$
P_{b l}=\frac{\Sigma b l o c k}{\Sigma c a l l}
$$

식 (3)에서 신규호의 합은 체크되는 10 초마다 발생한 신 규호들을 모두 합산하고, 차단된 호의 합 또한 매 체크되는 시간에 차단된 호들을 합산하게 된다. 그림 4는 셀 당 단말 의 수에 따른 신규호 블록율을 나타낸다. 단말이 속한 셀에 서만 채널을 탐색한 기존의 Single-Search Random 동적채 널할당 알고리즘에 비해서 채널 탐색 범위를 인접한 셀까 지 확장한 Group Search-based Max 동적채널할당 알고리 즘의 신규호 블록율이 개선된 것을 알 수 있다. 예를 들어, $\mathrm{i}=19$ 이고 $\mathrm{j}=5$ 인 환경에서 $\mathrm{k}=19 \mathrm{x} 4$ 개의 단말이 이미 연결되 어 있다면 그림 4에서 보는바와 같이 단말의 갯수가 9 개인 경우에 기존의 Single-Search Random 동적채널할당 알고 리즘에서는 신규호 블록율이 약 $20 \%$ 이기 때문에 한 셀 당 2 개정도의 단말이 차단되었다면 인접 셀에서 다시 사용 가능한 채널을 가져오는 경우의 수는 셀당 19!/(19-2)!= 


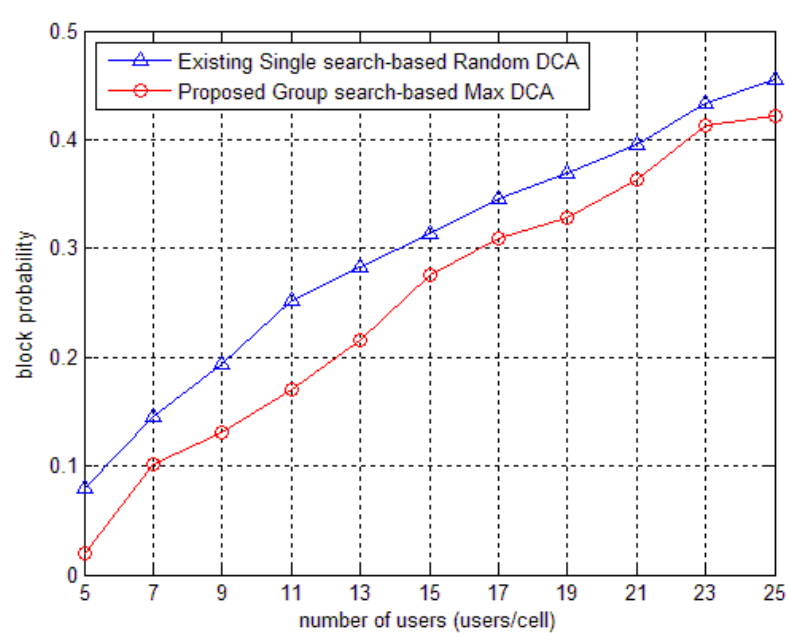

그림 4. 신규호 블록율

Fig. 4. New call blocking probability

$19 \times 18=342$ 가 되겠지만 제안하는 Group Search-based Max 동적채널할당 알고리즘에서는 신규호 블록율이 약 $12 \%$ 이 기 때문에 1 개의 단말이 차단되었다면 인접 셀에서 다시 사용가능한 채널을 가져오는 경우의 수는 셀당 19!/ (19-1)!=19로 급격히 감소하게 된다. 이는 단말이 위치한 셀에 할당 가능한 채널이 없거나 있더라도 주어진 SINR 문 턱치값을 만족하지 못해서 차단되는 신규호를 인접한 셀까 지 채널 탐색범위를 확장하여 채널을 할당 받게 함으로써 블록율을 낮추는 것이 인접 셀에서 사용가능한 채널을 가 져오는 경우의 수를 급격히 감소시킬 수 있다는 것을 보여 준다.

\section{2. 시스템 수율}

시스템 수율은 신규호 중에서 블록되지 않은 단말들이 할당받은 채널들의 채널용량 합이다.

$$
C=B \log _{2}(1+S I N R)
$$

식 (4)은 샤논의 이론으로 $\mathrm{C}$ 는 bps로 표시되는 채널용량 이고, $\mathrm{B}$ 는 채널의 대역폭이다. 본 논문에서는 단말이 기지 국으로부터 할당받은 채널로부터 구해진 SNIR을 적용하여
채널용량을 구하였다. 그림 5 는 셀 당 단말의 수에 5 에서 25 까지 증가할 때 $20 \mathrm{Mbps}$ 에서 $70 \mathrm{Mbps}$ 까지 변화하는 시스 템 수율의 차이를 보여주고 있다. 채널 탐색 범위를 인접 셀들로 확장한 Group Search-based Max 동적채널할당 알 고리즘의 경우가 채널 탐색 범위를 단말이 위치한 셀로 한 정한 경우에 비해 시스템 수율이 개선됨을 알 수 있다. 이는 채널을 할당받을 때 가장 큰 SINR을 갖는 채널을 할당받기 때문이다.

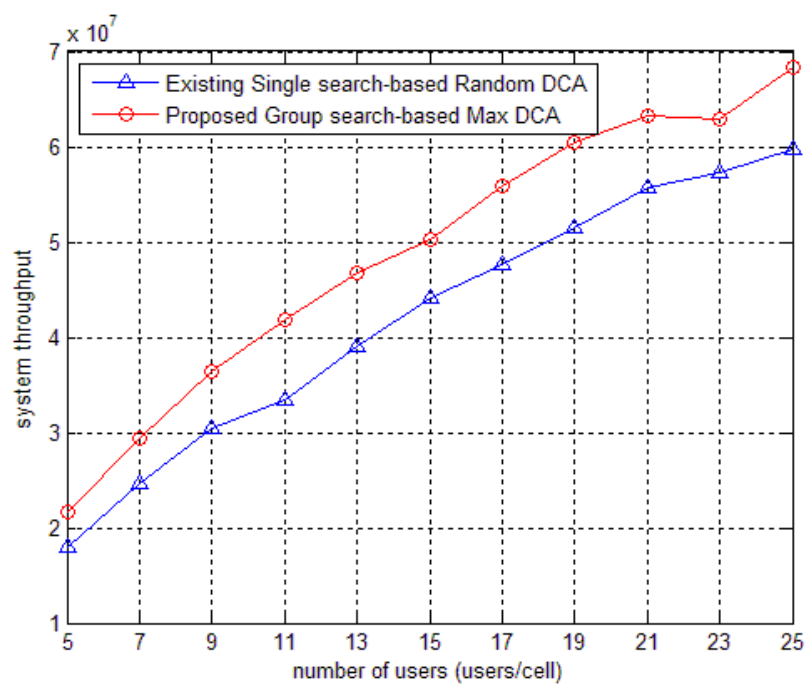

그림 5. 시스템 수율

Fig. 5. System throughput

\section{V. 결 론}

본 논문에서는 상향링크 셀룰러 환경에서 주파수 재사용 률이 1 인 경우에 채널을 할당할 때 채널 탐색 범위를 단말 이 속한 셀에 한정시킨 기존의 동적채널할당과 인접한 셀 까지 확장시킨 동적채널할당에 대해서 비교 분석하였다. 주파수 재사용률이 1 인 경우 인접한 셀에서 채널을 가져오 게 되면 동일 채널 간섭이 발생되고 그 결과 기존호의 $\mathrm{SINR}$ 이 저하되어 재할당해야 하는 경우가 생기게 되기 때 문에 신규호 블록율이 증가한다면 복잡한 연산 과정을 필 요로 하는 일종의 NP-hard 문제가 된다. 따라서 이러한 문 
제를 해결하기 위하여 채널 탐색 범위를 인접한 셀까지 확 장시킴으로써 셀 경계등에서 발생한 신규호 블록율을 감소 시키고 그 결과로 인접 셀에서 사용가능한 채널을 가져오 는 경우의 수에 따른 복잡한 연산 과정을 감소시킬 수 있게 된다. 시뮬레이션 결과, 제안한 방법에 의해서 신규호 블록 율과 시스템 수율이 향상됨을 확인 할 수 있었다.

\section{참 고 문 헌}

[1] H. Fujii, H. Yoshino, "Theoretical Capacity and Outage Rate of OFDMA Cellular System with Fractional Frequency Reuse", Vehicular Technology Conference 2008, pp.1676-1680, May 2008.

[2] Chong, P. H. J. and Leung, C., "Performance of reuse partitioning in cellular systems with mobile users", International Journal of Wireless Information Networks, 10(1), 17-31, 2003.

[3] I. Katzela, M. Naghshineh, "Channel assignment schemes for cellular mobile telecommunication systems: a comprehensive survey", IEEE Wireless Communications, pp. 10-31, Vol. 3, Issue 3, June 1996.
[4] E. Kudoh, F. Adachi, "Impact of frequency-selective fading on distributed dynamic channel assignment in a DS-CDMA multi-hop virtual cellular network", Vehicular Technology Conference 2004, vol 5, pp.3481-3485, 2004.

[5] 김효수, 김동회, 박승영, “하향링크 무선 통신 시스템에서의 Inter-cell DCA 알고리즘", 한국통신학회논문지, 제 33 권, 제7호, pp.693 701, 2008.

[6] Peter Stavroulakis, Terrestrial Trunked Radio - Tetra: A Global Security Tool, Springer, 7 Nov 2009.

[7] M. A. C. Lima, A. F. R. Araujo, and A. C. Cesar, Adaptive genetic Algorithms for Dynamic Channel Assignment in Mobile Cellular Communication Systems, IEEE Trans. Veh. Technol, vol.56, no.5, pp.2685-2696, Sept. 2007.

[8] S. Pinagapany and A.V. Kulkarni, Solving Channel Allocation Problem in Cellular Radio Networks using Genetic Algorithm, IEEE COMSWARE, pp.239-244, Jan. 2008.

[9] J. S. Lee and L. E. Miller, CDMA System Engineering Handbook, Cambridge Univ. Press, 1992.

[10] H. Harada and R. Prasad, Simulation and software radio for mobile communications, Artech House Publisher May 2002.

[11] Recommendation ITU-R M.1225, Guidelines for Evaluation of Radio Transmission Technologies for IMT-2000, 1997.

저 자 소 개

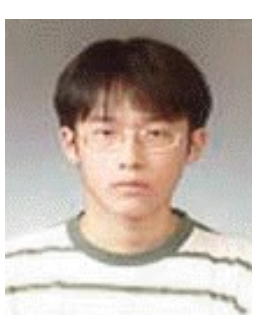

\section{유 도 경}

- 2010년 : 강원대학교 IT특성화대학 전자통신공학과 학사

- 주관심분야 : 차세대 이동통신시스템, 무선자원 알고리즘 및 멀티미디어 트래픽 최적화

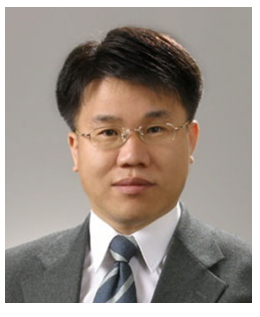

\section{김 동 회}

- 1989년 : 한양대학교 전자통신공학과 학사

- 1989년 1월 1997년 1월 : 삼성전자 전임연구원

- 1999년 : 한양대학교 전자통신공학과 석사

- 2005년 : 고려대학교 전파공학과 박사

- 2000년 8월 2005년 8월 : 한국전자통신연구원 이동통신연구단 선임연구원

- 2006년 3월 현재 : 강원대학교 IT대학 전자통신공학과 부교수

- 주관심분야 : 차세대 이동통신시스템, 무선자원 알고리즘 및 멀티미디어 트래픽 최적화, 무선액세스 프로프콜 